\title{
Pengembangan Sistem Informasi Manajemen Berbasis Web dalam Rangka Mendukung Evaluasi Kinerja Akademik dan Dosen di Akademi Manajemen Informatika dan Komputer Ibrahimy
}

\author{
Ahmad Homaidi ${ }^{*}$, Atika Lina ${ }^{2}$ \\ ${ }^{1}$ Program Studi Teknologi Informasi, Universitas Ibrahimy Sukorejo Situbondo \\ ${ }^{2}$ Program Studi Manajemen Informatika, Universitas Ibrahimy Sukorejo Situbondo \\ *Corresponding Author \\ E-mail: ${ }^{1}$ aidye89@gmail.com, ${ }^{2}$ atikaqween.01@gmail.com
}

\begin{abstract}
Abstrak
AMIK Ibrahimy Sukorejo Situbondo secara berkala mengadakan evaluasi kinerja dosen setiap akhir perkuliahan seperti pada waktu Ujian Akhir Semester. Kegiatan ini dilakukan untuk menilai kinerja dosen pada perkuliahan, dengan beberapa kriteria nilai yang telah ditentukan dari pihak AMIK Ibrahimy. Sistem evaluasi ini dilakukan dengan memberikan kuesioner kepada mahasiswa yang kemudian direkap sebagai laporan yang ditujukan kepada direktur. Dan hasil rekapan evaluasi kinerja dosen didistribusikan kepada masing-masing dosen, sehingga dapat mengetahui hasil evaluasi kinerja. Akan tetapi, dengan menggunakan prosedur tersebut membutuhkan waktu lama dalam proses penyebaran angket kuesioner kepada mahasiswa, hal ini terjadi karena tidak adanya petugas khusus dalam menangani kegiatan evaluasi kinerja dosen tersebut. Untuk membantu meminimalisir permasalahan tersebut, perlu dirancang Sistem Informasi Manajemen Evaluasi Kinerja Akademi dan Dosen AMIK Ibrahimy. Dengan adanya sistem ini diharapkan dapat membantu mempercepat pemrosesan penilaian yang selama ini cukup menyita waktu. Sistem ini dibuat menggunakan metode waterfall dengan beberapa tahapan yang dilakukan mulai dari Requirement sampai Maintenance. Dari hasil penelitian ini diharapkan dapat mengatasi masalah-masalah evaluasi kinerja yang selama ini terjadi. Hasil pengujian menjadi tolak ukur apakah sistem ini berjalan dengan baik atau tidak. Tingkat kesesuaian perancangan sistem manajemen evaluasi kinerja ini dapat membantu evaluasi terhadap pelayanan akademi dan kinerja dari dosen.
\end{abstract}

Kata Kunci: sistem informasi, evaluasi kinerja, berbasis web

\begin{abstract}
AMIK Ibrahimy Sukorejo Situbondo periodically conducts lecturers' performance evaluations at the end of each lecture such as during the Final Semester Examination. This activity is carried out to assess the performance of lecturers in lectures, with some predetermined value criteria from AMIK Ibrahimy. This evaluation system is carried out by giving questionnaires to students which are then recapitulated as a report addressed to the director. And the results of the lecturer performance evaluation are distributed to each lecturer, so they can find out the results of the performance evaluation. However, using this procedure takes a long time in the process of distributing questionnaires to students, this happens because there is no special officer in handling the lecturer performance evaluation activities. To help minimize these problems, it was necessary to design Management Information Systems for Academic Performance Evaluation and AMIK Lecturer Ibrahimy. The existence of this system was expected to help speed up the processing of assessments which have been quite time consuming. This system was made using the waterfall method with several stages carried out starting from Requirements to Maintenance. From the results of this study it was expected to overcome the problems of performance evaluation that have occurred so far. The test results became a benchmark whether the system was running well or not. The level of appropriateness of the design of the performance management evaluation system can help the evaluation of academic services and the performance of lecturers.
\end{abstract}

Keywords: information system, performance evaluation, web based 


\section{PENDAHULUAN}

AMIK Ibrahimy dalam rangka menjunjung tinggi nilai Tri Dharma perguruan tinggi memerlukan penilaian kinerja layanan akademi dan dosen yang berdasarkan Tri Dharma perguruan tinggi. Dedi Rianto Rahadi dalam Manajemen Kinerja Sumber Daya Manusia menyatakan, "kinerja pegawai harus dikelola atau dimanaj, terutama untuk mencapai produktivitas dan efektivitas dalam rangka merancang bangun kesuksesan, baik secara individu maupun organisasi"(Rahadi, 2010). Pelayanan akademi sebagai penjamin mutu internal bagi mahasiswa dalam perguruan tinggi salah satunya dalam bidang sumber daya manusia (SDM). Sebagaimana yang dikemukakan oleh Direktorat Penjamin Mutu Kementrian Riset dan Teknologi dalam Pedoman Sistem Penjamin Mutu Perguruan Tinggi, bahwa SPMI bertujuan untuk untuk meningkatkan mutu pendidikan tinggi secara berencana danberkelanjutan. Tujuan ini hanya dapat dicapai apabila perguruan tinggi telah mengimplementasikan SPMI dengan baik dan benar, dan luarannya dapat digunakan untuk akreditasi (Kemeristekdikti, 2016). Selain daripada hal tersebut, manajemen kinerja harus dimulai dari sejak tahap perencanaan prestasi dengan menetapkan apa atau yang bagaimana harus dicapai, dan kegiatan apa saja yang harus dilakukan untuk mencapainya (Ruky, 2006). Salah satu yang harus dilakukan untuk peningkatan mutu adalah dengan evaluasi kinerja sumber daya manusia, yaitu khususnya kaitannya dengan dosen. Karena dosen adalah salah satu komponen utama dalam sistem pendidikan pada perguruan tinggi. Peran, tugas, serta tanggung jawab dosen sangatlah penting dalam mewujudkan tujuan pendidikan nasional, yaitu meningkatkan kualitas mahasiswa dengan menguasai ilmu pengetahuan, teknologi, dan seni. Untuk melaksanakan fungsi, peran, dan kedudukan yang sangat strategis tersebut, diperlukan dosen yang profesional dalam proses belajar mengajar supaya bisa mencapai tujuan yang optimal (Rico \& Lestari, 2018). Sukses tidaknya seorang dosen dalam melaksanakan tugas yang telah dibebankan kepadanya tidak dapat dilihat dari kegiatan kesehariannya. Sangat diperlukan kegiatan evaluasi dosen yang bertujuan untuk meningkatkan profesionalme dosen dalam melaksanakan tugas.

AMIK Ibrahimy Sukorejo Situbondo secara berkala mengadakan evaluasi kinerja dosen setiap akhir perkuliahan seperti pada waktu Ujian Akhir Semester (UAS). Kegiatan ini dilakukan untuk menilai kinerja dosen pada perkuliahan, dengan beberapa kriteria nilai yang telah ditentukan, antara lain: 1) kurang; 2) cukup; 3) baik; dan 4) sangat baik; yang disajikan dalam bentuk angket kuesioner, pengisian kuisioner dilakukan oleh mahasiswa, lalu rekap kuesioner sebagai laporan yang ditujukan kepada direktur. Hasil rekap evaluasi tersebut kemudian diberikan kepada dosen yang bersangkutan untuk mengetahui hasil evaluasi selama satu semester (Ibrahimy, 2015). Prosedur yang dilakukan ini masih memakan banyak waktu dikarenakan tidak ada petugas khusus yang mengurus keperluan evaluasi kinerja tersebut (Febrianty \& Divianto, 2017). Berdasarkan permasalahan yang dialami oleh pihak AMIK Ibrahimy dalam mengukur kinerja akademi dan dosen, maka untuk membantu mengurangi atau meminimalisir permasalahan tersebut, perlu adanya penelitian tentang Manajemen Evaluasi Kinerja Akademi dan Dosen AMIK Ibrahimy.

\section{METODOLOGI}

Membangun sistem yang baik memerlukan tahapan-tahapan yang jelas untuk ditempuh, sehingga sistem yang dihasilkan benar-benar sesuai (Mutazam, Samsumar, \& Arwidiyarti, 2018). Oleh karena itu, dalam mengembangkan perangkat lunak (software) harus mengikuti model pengembangan sistem SDLC, yaitu System Development Life Cycle (Ahmad, 2016).

Perancangan dan pembangunan sistem informasi manajemen evaluasi kinerja akademi dan 
dosen di AMIK Ibrahimy ini menggunakan metode klasik dari model SDLC, yaitu metode waterfall. Metode waterfall yang digunakan untuk perancangan sistem ini dipilh karena cakupan sistem yang dibangun masih belum cukup besar, oleh karena itu metode ini dirasa cocok untuk pengembangan sistem evaluasi yang akan dibangun. Secara garis besar metode waterfall ini memiliki tahapan-tahapan sebagai berikut : Communication, Planning, Modelling, Construction, dan Deployment (Pressman, 2010). Gambaran dari tahapan metode waterfall ini dapat dilihat seperti pada gambar 1 di bawah ini.

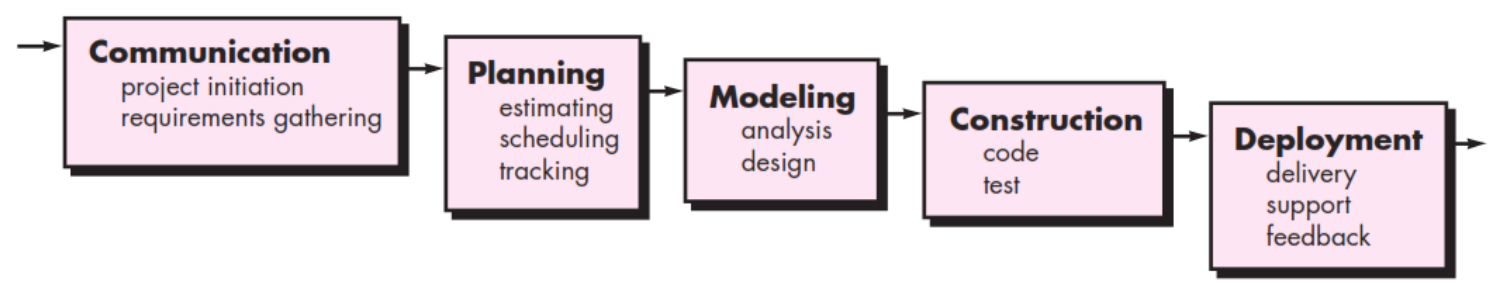

Gambar 1. Waterfall Method

Berikut tahapan yang dilakukan dalam membangun sistem evaluasi kinerja, yaitu:

1) Communication (Project Initiation \& Requirements Gathering)

Pada tahap ini peneliti melakukan komunikasi dengan pihak pengelola bagian evaluasi, yaitu ketua program studi untuk mengetahui tujuan dari sistem yang akan dibangun. Dari komunikasi tersebut dapat diketahui problem statement yang dihadapi dan mengumpulkan dokumen pendukung, serta membantu mendefinisikan fitur-fitur dari sistem yang akan dibangun.

2) Planning (Estimating, Scheduling, Tracking)

Tahap berikutnya adalah tahapan perencanaan yang menjelaskan tentang estimasi tugas-tugas teknis yang akan dilakukan, resiko-resiko yang dapat terjadi, sumber daya yang diperlukan dalam membuat sistem, produk kerja yang ingin dihasilkan, penjadwalan kerja yang akan dilaksanakan, dan tracking proses pengerjaan sistem.

3) Modeling (Analysis \& Design)

Tahapan ini adalah tahap perancangan dan pemodelan arsitektur sistem yang berfokus pada perancangan struktur data, arsitektur software, tampilan interface, dan algoritma program. Tujuannya untuk lebih memahami gambaran besar dari apa yang akan dikerjakan.

4) Construction (Code \& Test)

Tahapan Construction ini merupakan proses penerjemahan bentuk desain menjadi kode atau bentuk/bahasa yang dapat dibaca oleh mesin. Setelah pengkodean selesai, dilakukan pengujian terhadap sistem dan juga kode yang sudah dibuat. Tujuannya untuk menemukan kesalahan yang mungkin terjadi untuk nantinya diperbaiki.

5) Deployment (Delivery, Support, Feedback)

Tahapan Deployment merupakan tahapan implementasi aplikasi hasil penelitian ke pihak AMIK Ibrahimy, pemeliharaan software secara berkala, perbaikan aplikasi, evaluasi aplikasi, dan pengembangan aplikasi berdasarkan umpan balik yang diberikan agar sistem dapat tetap berjalan dan berkembang sesuai dengan fungsinya.

\section{HASIL DAN PEMBAHASAN}

\subsection{Identifikasi Current System}

Sistem yang evaluasi kinerja yang dilakukan di AMIK Ibrahimy selama ini masih 
menggunakan cara klasik, yaitu dengan melakukan penyebaran kuesioner saat ujian akhir semester. Proses ini melibatkan pihak SPMI, Staff, dan mahasiswa sebagai pelaku penilaian terhadap dosen maupun layanan akademi. Proses penilaian kinerja tersebut dapat digambarkan menggunakan flowchart dokumen sebagaimana terlihat pada gambar 2. Pada flowchart tersebut tergambar dengan jelas, siapa saja aktor yang terlibat dalam penilaian kinerja.

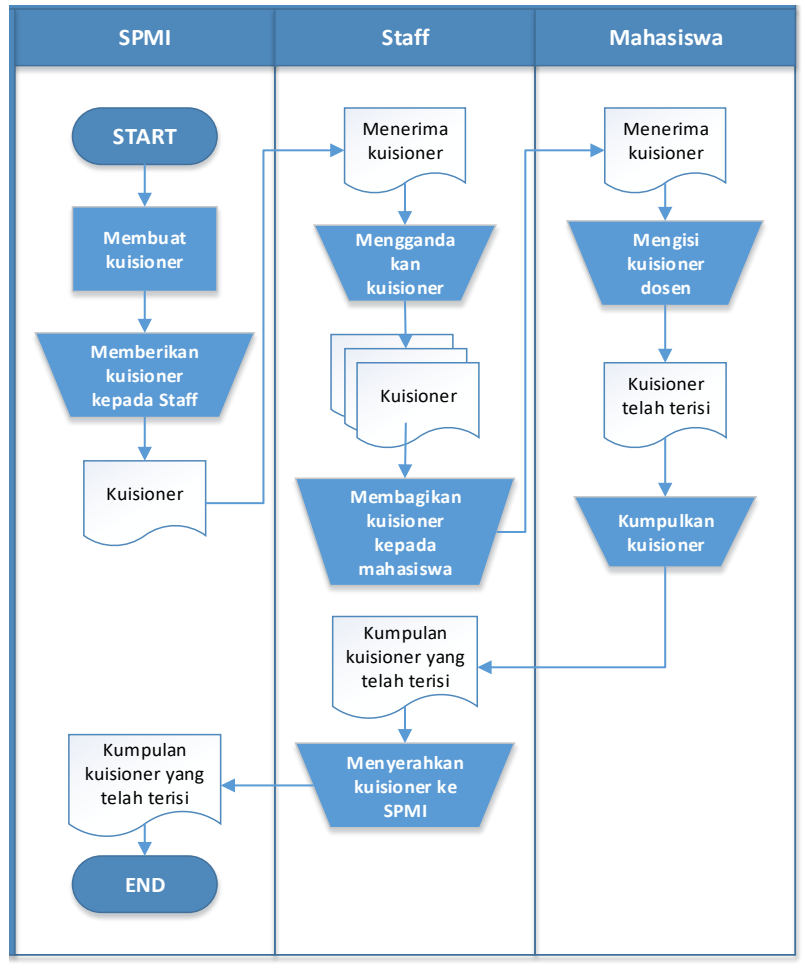

Gambar 2. Flowchart Penilaian Kinerja

Proses penilaian sebagaimana terlihat pada gambar 2 di atas, juga dapat dimodelkan menggunakan activity diagram (Nugroho, 2005) sebagaimana gambar 3 berikut ini

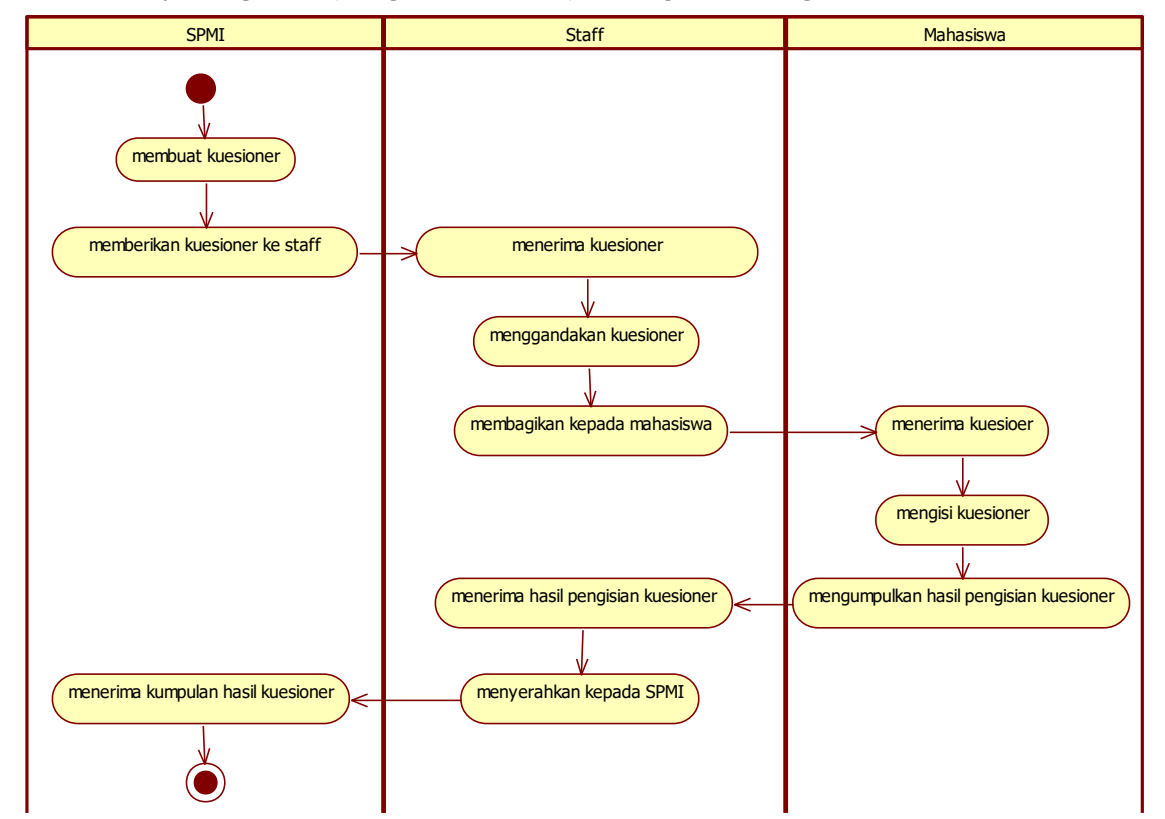

Gambar 3. Activity Diagram Penilaian 


\subsection{Use Case Diagram}

Use case diagram adalah suatu gambaran yang saling berhubungan antara aktor dengan use case dalam suatu sistem. Diagram ini sangat dibutuhkan untuk memodelkan proses dari suatu sistem sesuai dengan kebutuhan dan harapan pengguna (Nugroho, 2005).

Sistem Informasi Evaluasi Kinerja (SIMEKI) akademi dan dosen AMIK Ibrahimy yang dirancang ini aktor yang berperan aktif dalam sistem ini adalah mahasiswa sebagai aktor yang berperan sebagai pemberi nilai kinerja dan SPMI sebagai perangkum hasil evaluasi (Pangabean, 2016). Secara garis besar kegiatan dari aktor-aktor tersebut dapat dilihat sebagaimana use case diagram yang digambarkan dalam gambar 4 berikut ini.

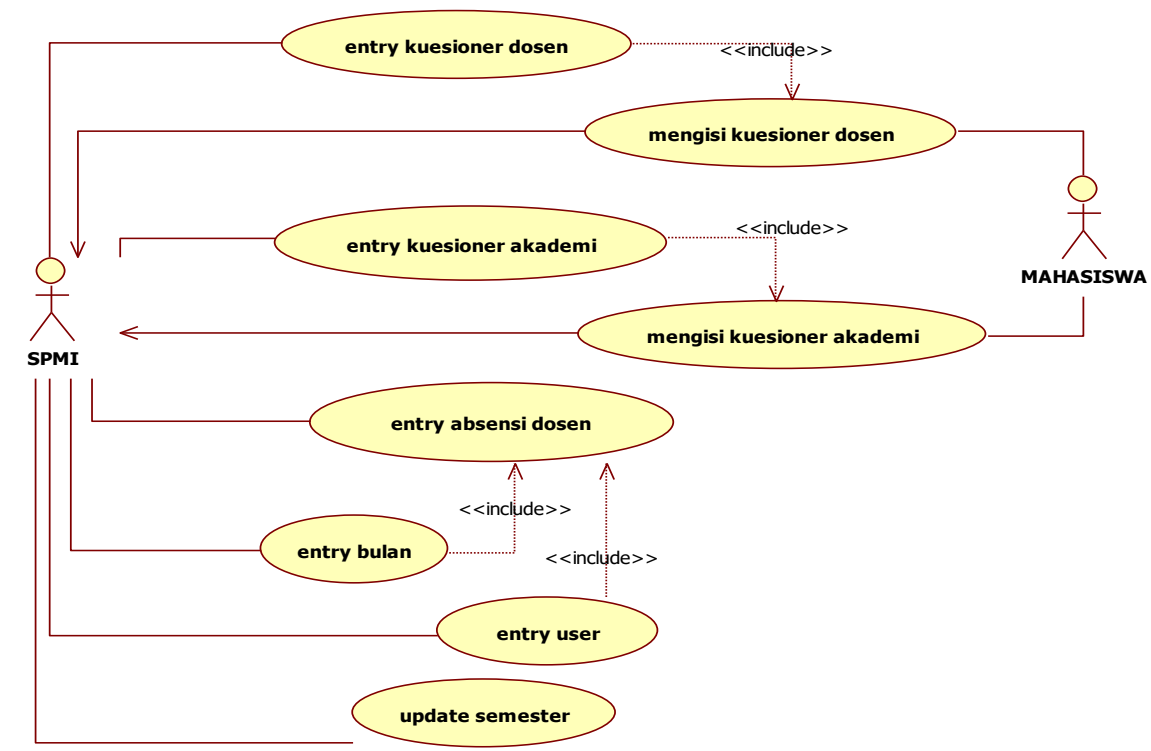

Gambar 4. Use Case Diagram SIMEKI

Dari pemodelan dengan use case diagram di atas dapat diketahui bahwa aktor Mahasiswa sebagai aktor utama berperan aktif untuk memberikan penilaian kepada dosen yang mengampu mata kuliah di semester aktif serta memberikan penilaian terhadap layanan akademi yang diterima selama semester tersebut pula. Sedangkan SPMI melakukan banyak kegiatan meliputi penyediaan kuesioner, entri absen, setting bulan, update semester dan menerima rekap hasil penilaian dari mahasiswa. Dari use case tersebut dapat digambarkan kebutuhan-kebutuhan selanjutnya yang seharusnya dipenuhi dalam sistem yang dibangun.

Agar sistem penilaian evaluasi kinerja ini dapat berjalan dengan yang diharapkan, maka pihak SPMI harus memperhatikan tahun ajaran dan semester yang aktif pada sistem informasi akademik. Hal ini dikarenakan data utama yang digunakan untuk penilaian sistem evaluasi kinerja ini terdapat pada database sistem informasi akademik yang memuat distribusi mengajar dosen sesuai dengan tahun akademik, semester, kampus, dan kelas. Hal ini juga dilakukan agar data yang terdapat dalam sistem penilaian kinerja ini terintegrasi dengan baik dengan database yang ada pada sistem informasi akademik.

\subsection{Class Diagram}

Class diagram digunakan untuk menampilkan beberapa kelas yang disertai dengan atributatribut di dalamnya, di mana kelas-kelas tersebut saling berelasi dengan yang lainnya sesuai 
sistem yang akan dikembangkan. Class diagram dalam perancangan sistem ini digambarkan pada Gambar 5. Pada gambar tersebut terlihat bagaimana relasi antar class, dan juga terlihat semua data berasal dari database siakad. Pada gambar tersebut dapat kita lihat bagaimana peranan database sistem informasi akademik yang menjadi sumber data.

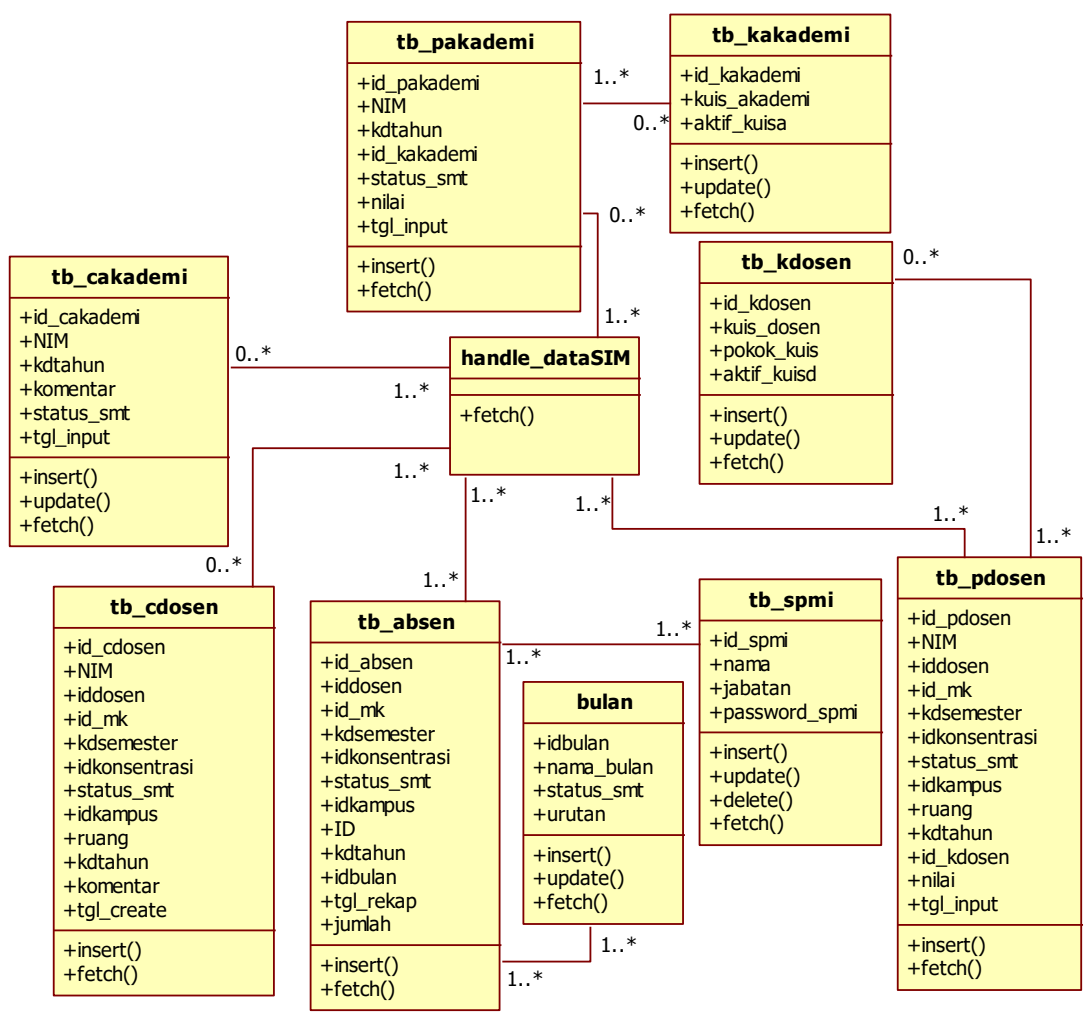

\subsection{Sequence Diagram}

Gambar 5. Class Diagram SIMEKI

Sequence diagram menggambarkan aktifitas dari pengguna mulai dari awal menggunakan aplikasi, mulai dari tampilan yang dalam hal ini biasanya digambarkan dengan Boundary, pemrosesan data tak terlihat yang dilakukan di control, dan penyimpanan sampai ke database yang digambarkan dengan simbol entity. Sequence diagram pada sistem ini meliputi sequence diagram untuk penilaian kinerja dosen, penilaian kinerja akademik dan rekapitulasi absen dosen. Sequence diagram penilaian dosen menggambarkan bagaimana mahasiswa dapat memberikan penilaian terhadap dosen yang mengampu mata kuliah sesuai dengan yang di KRS oleh mahasiswa tersebut. Prosesnya adalah mahasiswa login sesuai dengan nomor pokok mahasiswa, selanjutnya mahasiswa dapat memilih menu penilaian dosen di menu utama, setelah itu akan ditampilkan data KRS yang dilakukan oleh mahasiswa tersebut di tahun akademik dan semester yang aktif. Selanjutnya mahasiswa dapat memilih dosen dengan mata kuliah mana yang akan diberi penilaian oleh mahasiswa tersebut. Setelah itu barulah dimunculkan form untuk memberikan penilaian yang datanya akan disimpan dalam database. Sequence diagram dalam penilaian dosen ini dapat dilihat pada gambar 6 di bawah ini. 


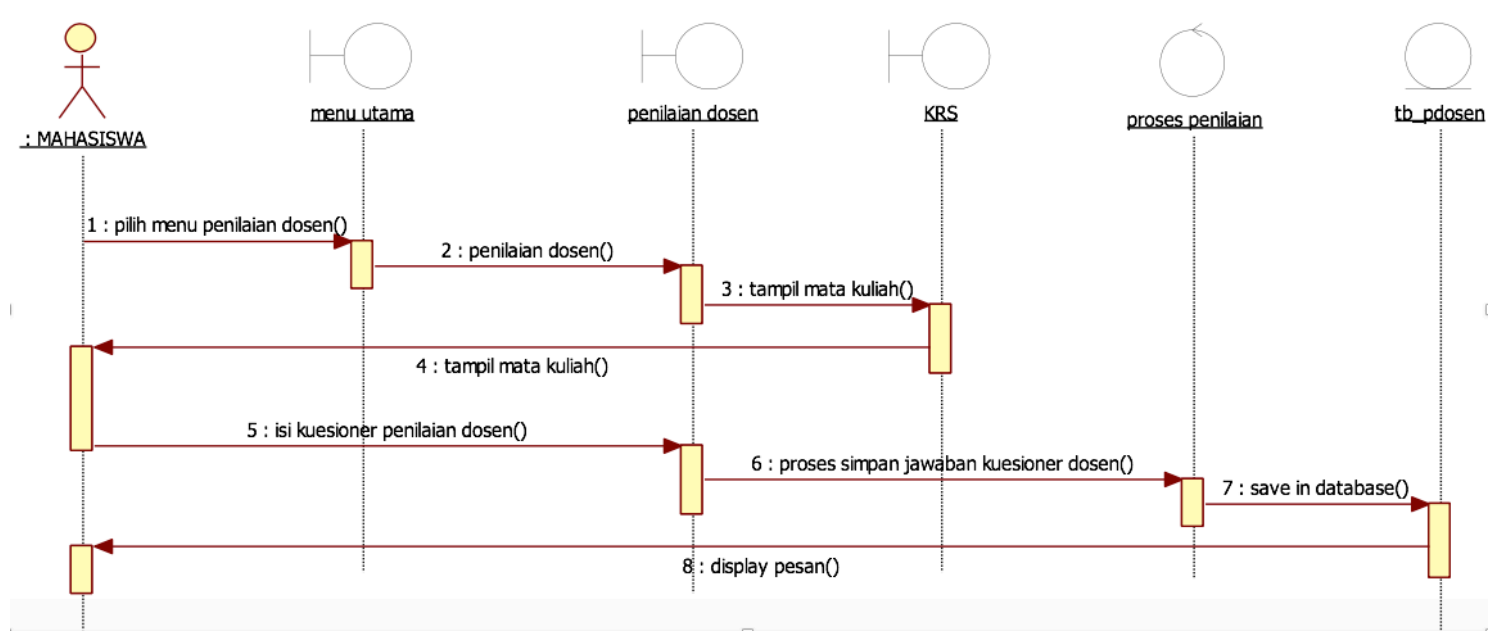

Gambar 6. Sequence Diagram Penilaian Dosen

Berikutnya adalah sequence diagram untuk penilaian layanan akademi. Penilaian akademi ini tidak jauh berbeda dengan sistem penilaian dosen, akan tetapai penilaian akademi ini lebih simple. Pada sistem yang dirancang ini saat memilih penilaian akademi akan dimunculkan form untuk penilaian akademi. Sistem penilaian akademi ini digambarkan dengan sequence diagram sebagaimana gambar 7 berikut ini.

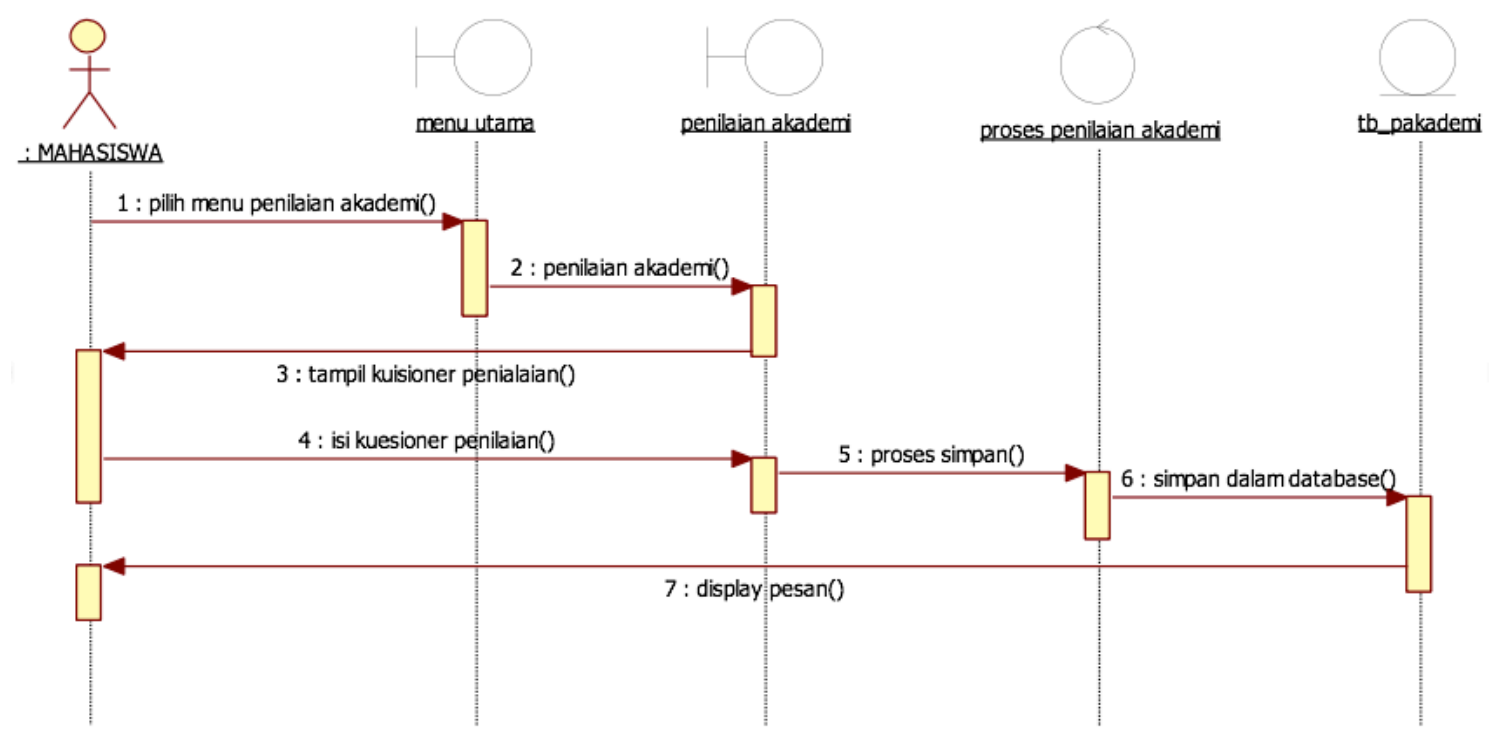

Gambar 7. Sequence Diagram Penilaian Akademi

Sequence diagram berikutnya adalah tentang rekap absensi kehadiran dosen dalam memberi mata kuliah. Sequence diagram untuk rekap absensi dosen dapat dilihat pada gambar 8 di bawah ini. 


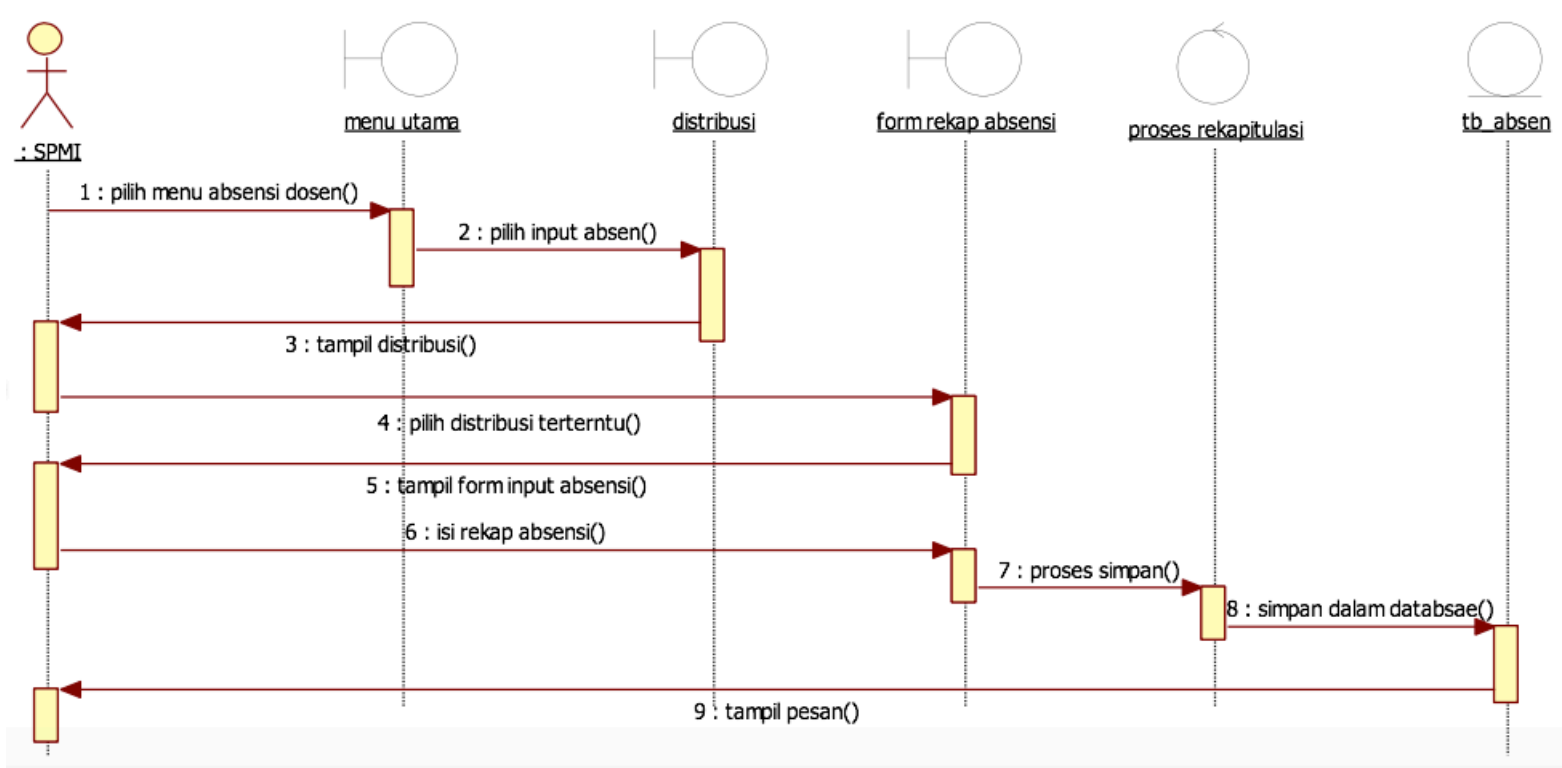

Gambar 8. Sequence Diagram Rekap Absen Dosen

Pada gambar di atas dapat dilihat bagaimana proses rekap absensi yang dilakukan di sistem yang dibangun. Prosesnya adalah dengan memilih menu absensi dosen dan sub menu input absen dosen, selanjutnya akan ditampilkan distribusi mengajar dosen. Dari distribusi tersebut dipilih dosen mana yang akan dimasukkan absen kehadirannya, maka akan ditampilkan form untuk mengisi rekap absensi kehadiran dosen.

3.5 Flowchart

Flowchart merupakan suatu bagan yang digunakan untuk menggambarkan alir proses sesuai dengan program atau prosedur sistem yang berjalan, bagan ini digunakan untuk menggambarkan sistem secara logis (Sitorus, 2015). Flowchart (bagan alir) yang digunakan untuk menggambarkan sistem di sini adalah flowchart system. Flowchart ini digunakan untuk menggambarkan proses dari sistem. Gambar 9 adalah bagan alir sistem penilaian dosen.

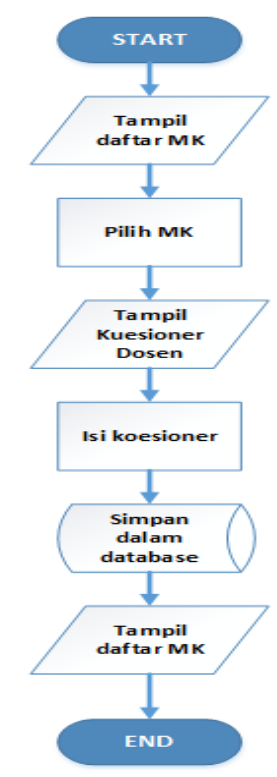

Gambar 9. Flowchart Penilaian Dosen 
Flowchart sistem pada sistem informasi manajemen evaluasi kinerja ini tidak hanya untuk penilaian dosen saja, tetapi juga ada untuk penilaian akademi dan rekap absensi dosen. Namun secara sistem proses tersebut tidak jauh berbeda dengan flowchart penilaian dosen pada gambar 9 tersebut di atas.

\subsection{Implementasi}

Sistem informasi manajemen evaluasi kinerja ini dirancang berbasis website dengan tujuan agar bisa diakses dari mana saja, terpenting ada koneksi internet. Sistem evaluasi kinerja akademi dan dosen ini dijalankan menggunakan browser, karena bahasa pemrograman yang digunakan adalah bahasa pemrograman yang berbasis server side, yakni PHP. Berikut adalah tampilan awal sistem yang dibangun dapat dilihat pada gambar 10 .

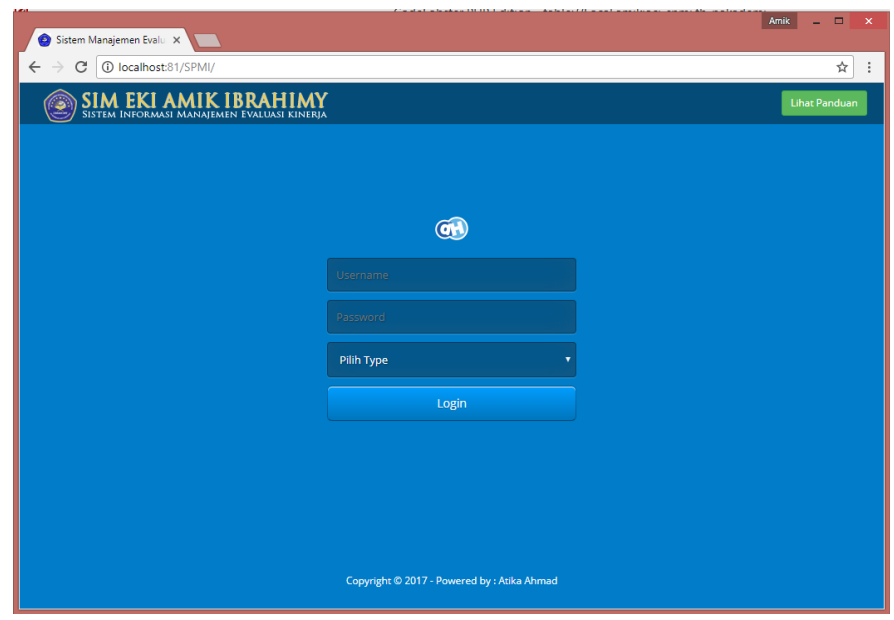

Gambar 10. Tampilan Awal SIMEKI

Untuk dapat melakukan akses ke halaman utama, maka mahasiswa dan SPMI harus melakukan login sesuai dengan username dan password yang sudah ditentukan. Untuk mahasiswa menggunkan nomor pokok mahasiswa dan dengan password yang sudah ditentukan. Setelah login maka user akan diarahkan ke halaman utama sebagaimana gambar 11 berikut ini.

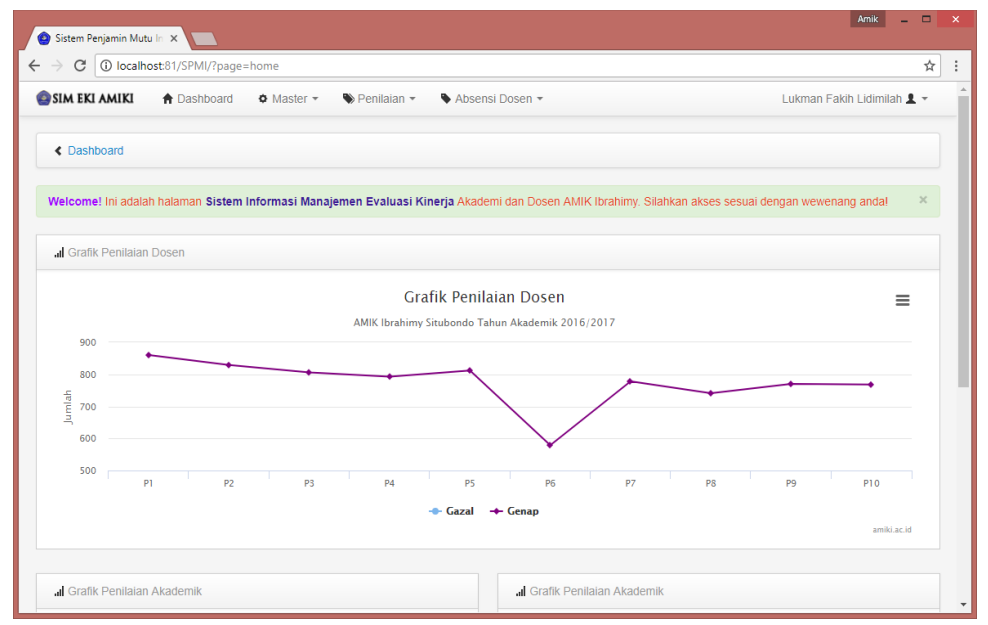

Gambar 11. Halaman Utama

Setelah user mahasiswa berhasil login, maka akan masuk ke dalam halaman utama 
sebagaimana dijelaskan di atas. Selnjutnya dapat memberikan penilaian dosen dan akademi. Untuk memberikan penilaian dosen maka mahasiswa dapat memilih menu penilaian, dilanjut dengan penilaian dosen. Kemudian ditampilkan dosen dengan mata kuliah yang di KRS di semester yang aktif. Setelah itu mahasiswa dapat memilih dosen yang akan diberikan penilaian dan form penilaian pada sistem dapat dilihat sebagaimana gambar 12 .

Pada form tersebut akan ditampilkan kuesioner indikator kinerja dosen yang mana mahasiswa dapat memberikan penilaian sesuai indikator tersebut dan dapat memberikan saran atau komentar untuk dosen yang bersangkutan. Hasil evaluasi ini nantinya akan digunakan oleh pihak SMPI dalam melakukan evaluasi terhadap kinerja dosen yang telah dilakukan.

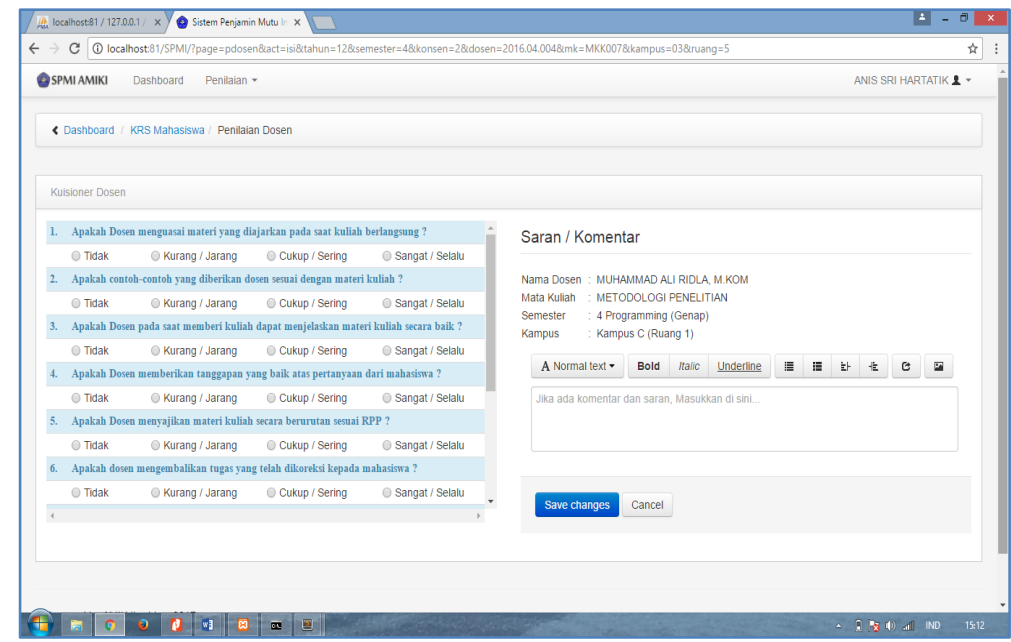

Gambar 12. Form Penilaian Dosen

Selain penilaian dosen sebagaimana gambar di atas, terdapat penilaian akademi yang dilakukan dalam sistem ini. Hal ini agar sistem ini dapat memberikan evaluasi terhadap layanan yang dilakukan pihak AMIK Ibrahimy secara umum. Form penilaian layanan akademi tidak jauh berbeda dengan sistem penilaian yang dilakukan terhadap dosen, hanya saja jawaban dari penilaian ini berisikan nilai "Ya" dan "Tidak", tidak menggunakan interval angka sebagaimana yang dilakukan pada penilaian dosen. Gambar 13 adalah gambar form untuk memberikan penilaian layanan akademi oleh mahasiswa.

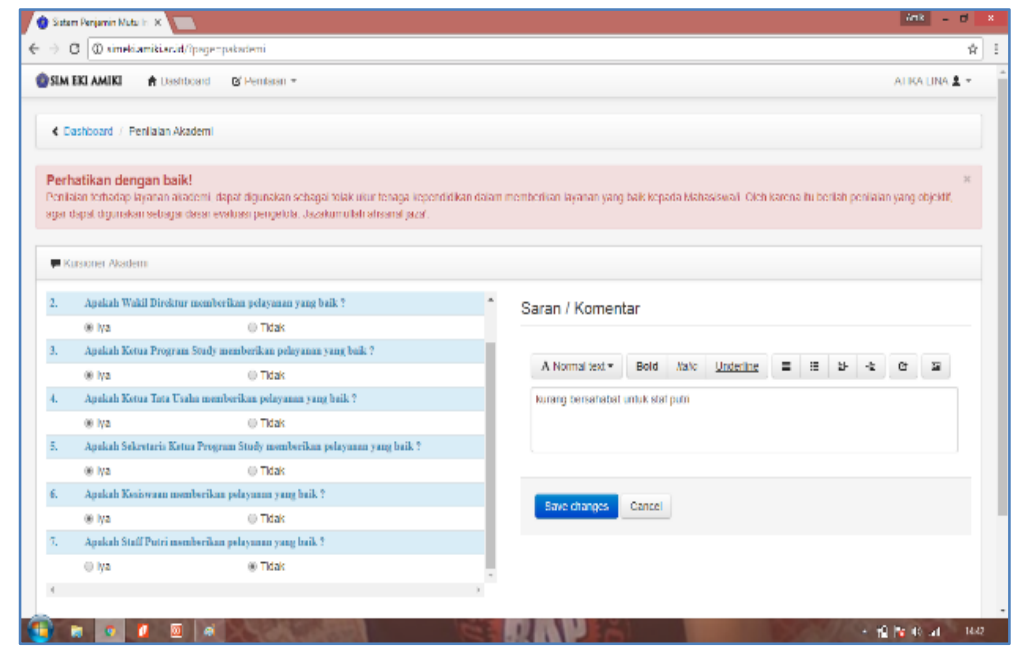

Gambar 13. Form Penilaian Akademi 
Selain sistem penilaian dosen dan akademi yang dilakukan oleh mahasiswa, juga terdapat evaluasi keaktifan dosen yang dilakukan oleh pihak SPMI, yang dalam hal ini SPMI melakukan rekapitulasi absensi kehadiran dosen dalam memberikan perkuliahan. Gambar 14 merupakan gambar form rekap absensi dosen dalam sistem evaluasi kinerja. Untuk pengisian absensi dosen seperti pada form input absensi dosen pada gambar 14 di bawah ini, dilakukan dengan pemilihan distribusi mata kuliah terlebih dahulu. Ketika pemilihan dalam distribusi dengan otomatis form input absensi dosen akan menyesuaikan dengan distribusi yang dipilih, seperti nama dosen, mata kuliah, semester, kampus, dan ruang.

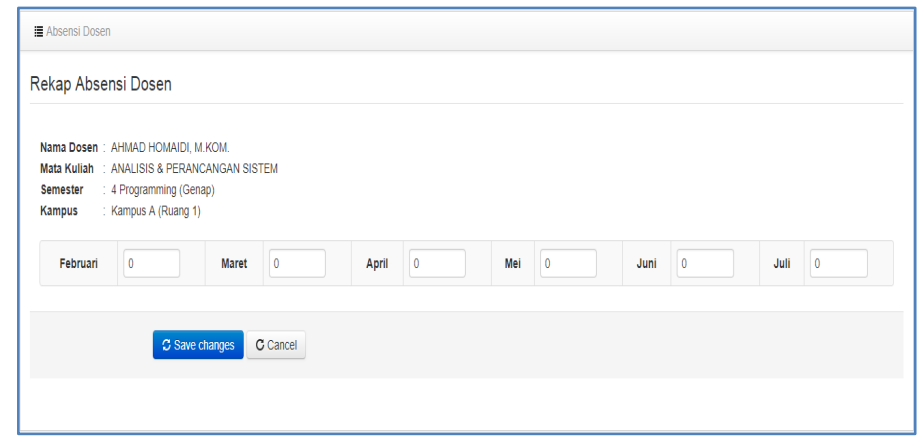

Gambar 14. Form Rekap Absen Dosen

Setelah semua data penilaian akademi dan dosen serta rekap absensi selesai dilakukan. Tentunya hasil inputan data tersebut menghasilkan sebuah laporan yang dapat dibuat sebagai bahan laporan kepada pimpinan tertinggi yang dalam hal ini adalah Direktur AMIK Ibrahimy. Selain itu juga laporan-laporan tersebut dapat disalurkan kepada dosen yang bersangkutan agar menjadi evaluasi untuk memperbaiki kinerjanya di semester yang akan datang. Gambar 15 berikut adalah output dari penilaian dosen.

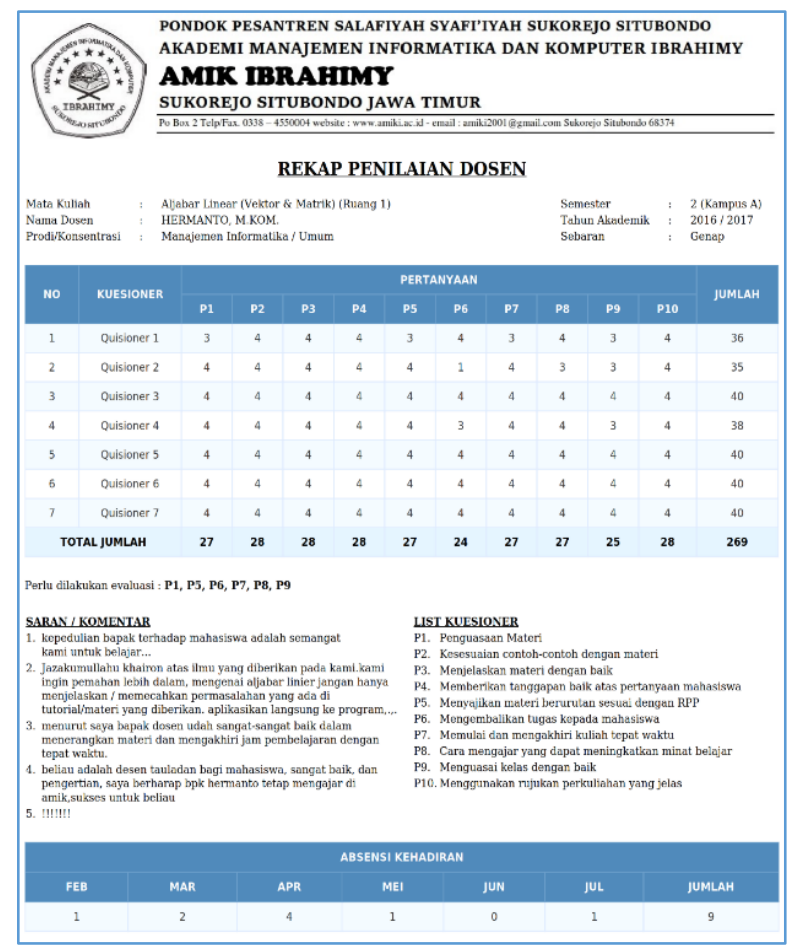

Gambar 15. Ouput Penilaian Dosen 
Selain output yang dapat dicetak secara langsung ataupun berentuk pdf, terdapat juga output laporan yang berbentuk grafik. Sebagaimana gambar 16 yang ada di bawah ini.

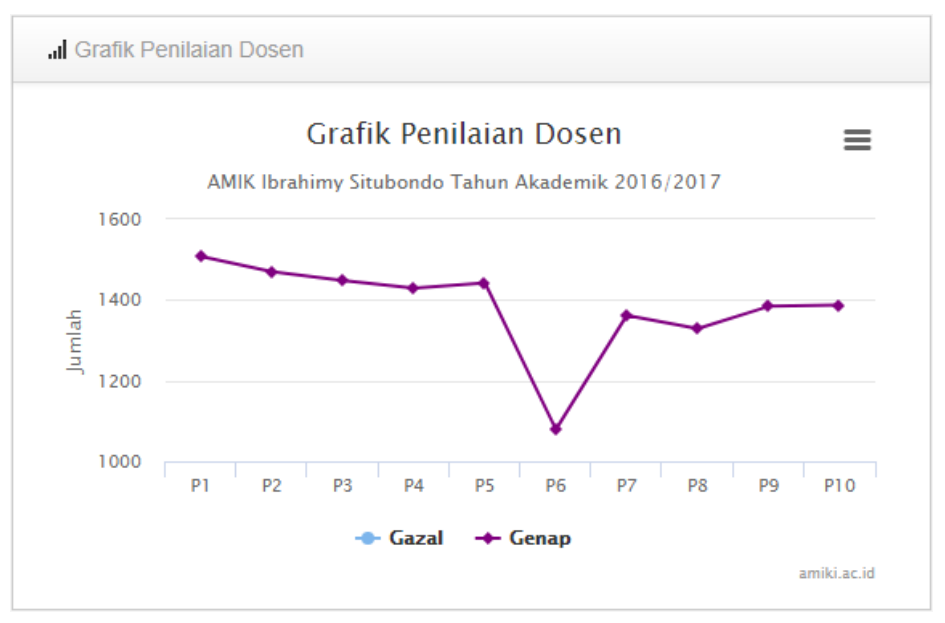

Gambar 16. Grafik Penilaian Dosen

Gambar 16 tersebut menggambarkan hasil rekap penilaian dosen secara keselruhan. Dari grafik tersebut dapat dilihat indikator mana yang paling tinggi dan mana yang paling rendah. Dari sini dapat dievaluasi bahwa kekurangan dan kelebihan dari dosen sesuai dengan indikator penilaian yang sudah diinputkan oleh mahasiswa. Selain grafik penilaian dosen sebagaimana pada gambar 16 tersebut, terdapat juga grafik untuk indikator penilaian layanan akademi yang didapat oleh mahasiswa. Grafik ini dibuat agar memudahkan melakukan evaluasi terhadap layanan akademi yang dilakukan oleh bagian-bagian di AMIK Ibrahimy. Grafik penilaian layanan akademi tersebut digambarkan pada gambar 17 berikut ini.

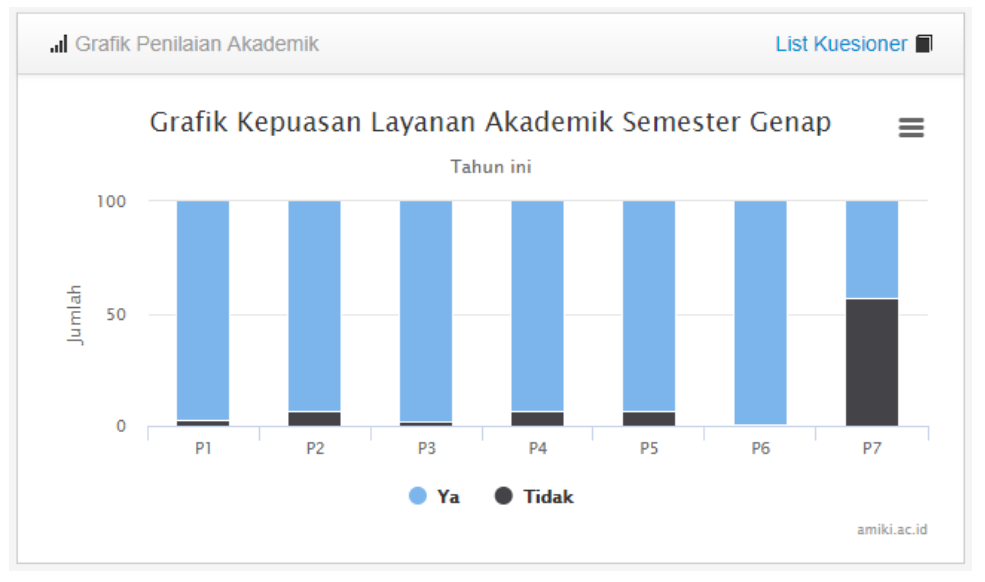

Gambar 17. Grafik Penilaian Akademi

Dari gambar 17 tersebut dapat tergambarkan tingkat kepuasan mahasiswa terhadap layanan yang mereka dapatkan dari tiap sektor pelayanan yang ada di AMIK Ibrahimy. Hasil penilaian ini dapat digunakan sebagai bahan evaluasi untuk perbaikan layanan yang lebih baik pada setiap sektor layanan.

Hasil pengujian ini berupa isian angket kepuasan terhadap penggunaan sistem yang bangun, apakah sesuai dengan kebutuhan atau tidak. Juga list daftar bug atau error yang terjadi pada sistem penilaian ini serta masukan-masukan dan saran untuk perbaikan sistem. Pengujian sistem 
diharuskan melibatkan banyak pihak yang berkaitan dengan sistem yang dibangun, khususnya pihak-pihak yang mempunyai akses terhadap sistem ini. Pihak-pihak terkait tersebut antara lain adalah mahasiswa aktif yang mempunyai peran penting dalam pengisian sistem penilaian ini. Dari sekian sample yang digunakan ini didapatkan hasil pengujian sebagaimana tabel 1.

Tabel 1. Rekap Hasil Pengujian Sistem

\begin{tabular}{|c|c|c|c|c|c|c|c|c|c|c|c|}
\hline \multirow{2}{*}{ Q } & \multicolumn{7}{|c|}{ Pertanyaan } & \multirow{2}{*}{ Jumlah } \\
\cline { 2 - 11 } & P1 & P2 & P3 & P4 & P5 & P6 & P7 & P8 & P9 & P10 & \\
\hline 31 & 108 & 108 & 112 & 106 & 109 & 107 & 103 & 114 & 111 & 101 & $\mathbf{1 0 7 9}$ \\
\hline
\end{tabular}

Keterangan:

Q : Jumlah Sample

P1 - P10 : Kuesioner Pengujian Sistem

Dari hasil pengujian tersebut terdapat beberapa catatan yang dapat dijadikan dasar untuk pengaplikasian sistem ini, apakah sudah siap atau belum siap untuk diaplikasikan. Hasil analisa uji coba aplikasi ini didapatkan hasil sebagai berikut;

$\begin{array}{lll}\text { Total/Sample } & : & 35 \\ \text { Max Nilai (100\%) } & : & 40 \\ \text { Prosentase Kepuasan } & : & 88 \%\end{array}$

Dari prosentase kepuasan yang telah dilakukan saat pengujian sistem ini menunjukkan $88 \%$ menunjukkan bahwa sistem ini dapat diaplikasikan untuk membantu mengevaluasi kinerja dari dosen dan akadmik. Sehingga tidak perlu lagi membuat kuisioner dalam bentuk kertas yang kemudian di rekap ulang.

\section{KESIMPULAN}

Sistem Informasi Manajemen Evaluasi Kinerja Akademi dan Dosen AMIK Ibrahimy Berbasis Web dapat dirancang dan dibangun menggunakan bahasa pemrograman PHP dan MySQL. Sehingga melalui proses testing dapat memberikan informasi yang valid secara efisien dan dapat dijadikan rujukan untuk mengukur tingkat kepuasan mahasiswa terhadap pelayanan akademi dan kinerja dosen. Kegiatan evaluasi kinerja akademi dan dosen yang pada awalnya belum maksimal karena proses yang dilakukan secara manual dapat teratasi dengan adanya sistem evaluasi yang baru, sehingga lebih maksimal dengan mendapatkan informasi secara cepat, tepat, akurat dan relevan. Selain itu semua, adanya aplikasi ini dapat menghemat waktu serta biaya untuk penyebaran kuesioner dan penginputan data kuesioner yang telah diisi mahasiswa. Untuk optimalisasi penerapan sistem evaluasi kinerja ini diperlukan komitmen pihak manajemen dalam pengaplikasiannya, sehingga sistem ini benar-benar dapat berjalan dengan baik.

\section{DAFTAR PUSTAKA}

[1] Ahmad, H. Sistem Informasi Akademik AMIK Ibrahim berbasis Web. Jurnal Ilmiah Informatika, 1(1), 17-23. 2016.

[2] Febrianty, \& Divianto. Evaluasi Kinerja Berdasarkan Implementasi Sistem Pengendalian Internal. Akuntabilitas: Jurnal Ilmu Akuntansi, 10(2), 193-210. 2017.

[3] Ibrahimy, A. Pedoman Akademik Akademi Manajemen Informatika dan Komputer Ibrahimy (1st ed.; A. Ibrahimy, ed.). Situbondo: Amiki Press. 2015. 
[4] Kemeristekdikti. Pedoman Sistem Penjamin Mutu Pendidikan Tinggi. Jakarta: Direktorat Penjamin Mutu. 2016.

[5] Mutazam, M., Samsumar, L. D., \& Arwidiyarti, D. Rancang Bangun Sistem Evaluasi Kinerja Dosen Dalam Perkuliahan Untuk Meningkatkan Kualitas Perkuliahan. Jurnal Teknologi Informasi Dan Komunikasi, 7(2), 74-87. 2018. Diakses pada https://jurnal.kominfo.go.id/index.php/jtik/article/view/1747.

[6] Nugroho, A. Rational Rose untuk Pemodelan Berorientasi Objek. Bandung: Penerbit Informatika. 2005.

[7] Pangabean, E. Sistem Pendukung Keputusan Evaluasi Kinerja Dosen Menggunakan Metode Fuzzy Simple Additive Weighting (FSAW). Jurnal Mantik Penusa, 19(1). 2016.

[8] Pressman, R. S. Software Engineering A Pratitioner's Approach. New York: McGraw-Hill. 2010.

[9] Rahadi, D. R. Manajemen Kinerja Sumber Daya Manusia. Malang: Tunggal Mandiri. 2010.

[10] Rico, \& Lestari, D. Perancangan Sistem Informasi Penilaian Kinerja Dosen Berbasis Web (Studi Kasus: Universitas Adiwangsa Jambi). Journal V-Tech (Vision Technology), 1(2), 4752. 2018. Diakses pada http://ejournal.unaja.ac.id/index.php/JVT/article/view/275.

[11] Ruky, A. S. Sistem Manajemen Kinerja (Performance Management System). Jakarta: Gramedia Pustaka Utama. 2006.

[12] Sitorus, L. Algoritma dan Pemrograman. Yogyakarta: Penerbit Andi. 2015. 